\title{
Transfers of anti-Waldensian material from a polemical treatise to a didactic text
}

\author{
Reima Välimäki*
}

Ulrich von Pottenstein translated Petrus Zwicker's anti-Waldensian treatise Cum dormirent homines (1395) in his large catechetical encyclopaedia (ca. 1410), written in Early New High German. The translation was dispersed in different chapters, transforming the reading experience of the anti-heretical work but at the same time adding a polemical element to a pastoral text.

The article discusses the historical context of Zwicker's original Latin treatise and Ulrich's translation, in particular the inquisitions against Waldensians that Zwicker led in Austria in the 1390 s, as well as Ulrich's ecclesiastical career. The second part of the article explores solutions Ulrich had to employ when he translated a text for a lay audience that was not only polemical but also required from its readers a basic understanding of exegesis. Finally, the reasons for Ulrich's decision to translate Zwicker and the composite nature of the pastoraldidactic text with polemical passages is discussed. As for polemical treatises in general, the motivation behind Ulrich's translation was to defend the Church against its enemies. Ulrich's vernacular text had potential to extend the audience of a Latin anti-heretical treatise, but his catechetical encyclopaedia was too large and tedious to read to ever become a popular work. The article proposes that the polemical nature of the original was not mitigated in the process. On the contrary, Ulrich does not shy away from using denigrating or violent language, and polemical style is an essential part of his catechesis. A further study of polemical style in late-medieval pastoral and didactic works, especially vernacular texts, is proposed as a promising area of future research.

Keywords: heresy; Waldensians; anti-heretical polemics; pastoral care; inquisition; Zwicker, Petrus; Ulrich von Pottenstein; translation; Early New High German, Wiener Schule

\section{Introduction}

At the turn of the fifteenth century Ulrich, parson of Pottenstein in Austria, toiled with his magnum opus. He had set himself to compile what he saw as essential theological knowledge and translate it from Latin into the Early New High German vernacular. The result, when he finished it sometime around 1410, was a huge four-part catechetical treatise. The whole work consists of 70 chapters divided into four parts; Pater noster (chs. 1-13), Ave Maria (14-20), Credo (21-42) and Magnificat/Decalogus (43-70). It covers about 1200 manuscript folios, but it probably never existed as a single manuscript. Despite the fact that it is often designated, * Correspondence details: Reima Välimäki, University of Turku, Department of Cultural History. Email: reima.
valimaki@utu.fi. 
following the fundamental study by Gabriele Baptist-Hlawatsch, as ra catechetical work $\triangleleft{ }^{1}$ perhaps a more fitting description is Klaus Wolf's scatechetical Encyclopediar (Katechetische Enzyklopädie). ${ }^{2}$ The treatise should be viewed more as a German compendium of theological knowledge translated from Latin sources than a practical guide to Christian life and doctrine intended for the laity. ${ }^{3}$ Its gigantic size prevented its transmission. It was simply too massive to be practical and too expensive to produce. The manuscript tradition of Ulrich von Pottenstein's catechetic summa is indeed very small, only eleven extant manuscripts (and one very short fragment), ${ }^{4}$ none of which comprises the whole treatise.

Ulrich drew from a wide range of Latin sources, and he cites extensively patristic and medieval authors. However, the Latin tradition Ulrich translated and transmitted came mainly from three compilations, recognised by Baptist-Hlawatsch: Gratian's Decretum, William Peraldus's popular Summa de vitiis et virtutibus (written before 1250) and an unidentified theological compilation containing at least Thomas Aquinas's Summa theologiae secunda secundae. At times Ulrich inserts longer passages of his own, but often he adds only short introductory or explanatory clauses and loyally translates whole chapters from his sources, to the extent that the treatise occasionally resembles a translation of William Peraldus's work. ${ }^{5}$ In addition to these compilations, Ulrich translated individual treatises or parts from them, only few of which have been recognised. ${ }^{6}$ This article concentrates on transfers of anti-heretical material from a particular text: the Celestine inquisitor Petrus Zwicker's anti-Waldensian treatise Cum dormirent homines, written in 1395. The treatise spread quickly, above all in Austria, Bohemia and Southern Germany, and with its circa 50 manuscript copies it became the standard polemical work on Waldensianism in German-speaking Europe in the fifteenth century. ${ }^{7}$ Ulrich's translation of Zwicker's treatise is an intriguing case, not only in relation to its immediate context, the persecution of Austrian Waldensians, but to the topic of this volume, the construction of polemics and transfers between other genres of literary interaction. The translation is an attempt not only to cross the language barrier between Latin and Early New High German, but also to assimilate a Latin polemical treatise, written against a specific enemy, the Waldensians, into a framework of catechetic summa discussing thematically the key concepts, questions and problems of late medieval Catholic Christianity. setzungsliteratur, 357; Baptist-Hlawatsch, Einführung, 20*-21* and Zwicker's Cum dormirent homines discussed in this article. In addition, Hermann Menhardt found passages treating Cathars that he traced back to the thirteenthcentury treatise by Reinerius Sacconi, see Menhardt, Funde zu Ulrich von Pottenstein, 170-171. It is probable that Ulrich's source was a version of the compilation by the Anonymous of Passau (ca. 1260) that contained Reinerius's treatise. On this compilation, see Patschovsky, Passauer Anonymus; Nickson, >Pseudo-Reinerius Treatise.

7 The fundamental studies on Zwicker's treatise are: Biller, Anti-Waldensian Treatise; Segl, Waldenser in Österreich; Modestin, Anti-Waldensian Treatise; Välimäki, Awakener of Sleeping Men, 77-114. A monograph based on my dissertation will be published by the York Medieval Press in 2019. 
In addition, the assumed and intended audience changed from the clergy to the laity. The exact dating of Ulrich's treatise is not known, but Gabriele Baptist-Hlawatsch has proposed that Ulrich started to compose it during the 1390 s and the whole work was finished before Ulrich received the diaconate at Enns-Lorch in 1411/12. ${ }^{8}$ In any case, we can safely speak of a contemporary reception of Zwicker's treatise.

I will first provide a brief historical context for Zwicker's treatise and Ulrich's translation. I will then discuss how Ulrich assimilated Zwicker's text into his catechetical encyclopaedia. He translated the whole text, but dispersed it across multiple chapters. He also expanded the text, providing further expositions. This changed the nature of the text, and the comparison between the two offers an excellent opportunity to explore the common ground between pastoral-didactic and polemical anti-heretical text. I will conclude the article by discussing the nature of the late-medieval religious polemical genre in the light of Ulrich von Pottenstein's translation. Almut Suerbaum has remarked that the anti-heretical sermons of Berthold of Regensburg were primarily aimed at the lay audience, castigating their mistakes and warning about heresy. ${ }^{9}$ Ulrich's didactic text has a similar function; it both provides guidance on the good Christian life and warns about error. As such, it distances itself from the imagined audiences and goal of Zwicker's treatise, which, at the rhetorical level, addresses the heretics and aims at their conversion and refutation of their errors. In a way, the structure of Ulrich's catechetic encyclopedia is more effective in juxtaposing the desired Christian modus vivendi and heretical error than the conventional anti-heretical treatise.

Ulrich von Pottenstein and his catechetic treatise have mainly been studied by Germanists, and Ulrich is best known for his popular fable translation, Cyrillusfabeln, which, unlike the catechetic treatise, was printed in the incunabula period..$^{10}$ Ulrich was a representative of the Wiener Schule of authors, translators and compilers connected to the University of Vienna, the ducal court and other secular lords and patrons. A central characteristic of the group, according to modern concepts and definitions, was a practically oriented attitude towards theology and other academic disciplines instead of purely scholarly speculation. They offered German devotional literature to lay audiences, although their readers included many members of the clergy and religious orders. The school's representatives include figures such as Thomas Peuntner and Heinrich von Langenstein. ${ }^{11}$ The education of laity, however, did not imply their emancipation. The Wiener Schule's message emphasised the doctrinal authority of the Church. Their vernacular devotional literature avoided controversial questions and guided the laity to orthodox piety as defined and instructed by the clergy. ${ }^{12}$ The previous scholars have commented on the anti-Jewish and anti-Hussite writings of the Wiener Schule, ${ }^{13}$ and my observations on Ulrich's anti-Waldensian translation expand our understanding about the role of the group in support of the state and the Church in early-fifteenth-century Austria.

8 Baptist-Hlawatsch, Einführung, $20^{*}-22^{*}$.

9 Suerbaum, Language of Violence, 128, 130. See below.

10 Baptist-Hlawatsch, Einführung, 13; Bodemann-Kornhaas, Cyrillusfabeln, 55-73.

11 On the Wiener Schule and its mission, see Hohmann, Bemerkungen zur Übersetzungsliteratur; Wolf, Hof - Universität - Laien; Wolf, Die sstaatstragender Rezeption.

12 Williams-Krapp, Observanzbewegungen, 14-15; Williams-Krapp, Zur literarischen Laienpastoration, 81-83; Wolf, Hof - Universität - Laien, 137.

13 See $n .36$ below. 
The connection between the Cum dormirent homines and Ulrich von Pottenstein's catechetic work is not actually a recent discovery. Hermann Menhardt pointed it out in 1953, although he followed the then prevailing false attribution of Cum dormirent homines to Peter von Pillichsdorf, a Viennese theologian and university scholar. ${ }^{14}$ Menhardt also presented a collation of Zwicker's treatise (following the page numbers of the 1613 edition) and the Credo part of Ulrich's treatise according to its earliest and most complete manuscript copy in Cod. 3050 of the Austrian National Library. ${ }^{15}$ He noticed that Ulrich had translated almost the complete text of Zwicker's treatise, but despite his meticulous work Menhardt was unable to locate the last chapter of the Cum dormirent homines, the chapter on denial of oaths. This led him to speculate whether it had been lost with the last, ripped-off quire of Cod. 3050, or whether Ulrich never used it. ${ }^{16}$ Ulrich did indeed translate Zwicker's defence of oath-taking, but not, unlike all other chapters, for the Credo part, but for his exposition of the Decalogue. ${ }^{17}$

However, since Menhardt, only passing remarks on the heresy sections in Ulrich's treatise have been made. Peter Segl referred to them in a paper published in 2006, suggesting further study on the topic. ${ }^{18}$ There were at least two attempts to edit the parts including the translation from the Cum dormirent homines in the 1990 s as a part of larger research projects at the University of Würzburg-Eichstätt, but the prepared edition was never completed. ${ }^{19}$ There are editions of the Pater noster-part and the First Commandment, but these do not include the anti-Waldensian sections. ${ }^{20}$ After Menhardt, my dissertation has been the first study to address Ulrich's translation of the Cum dormirent homines in any detail. ${ }^{21}$ There my focus was on Ulrich von Pottenstein's role in the dissemination of Zwicker's anti-Waldensian message, while this article concentrates on Ulrich's translation as a pastoral text verging on the polemical.

Petrus Zwicker, Ulrich von Pottenstein and the persecution of Austrian Waldensians in the 1390 s Ulrich von Pottenstein rose among the ranks of the Austrian clergy at the turn of the fifteenth century. His career took place at a time when it was impossible for a clergyman of his status not to run across the Waldensians and their persecutors. There had been Waldensians in Austria at least from the second half of the thirteenth century onwards. An author who probably was an inquisitor and a Dominican, but who is known only as the Anonymous of Passau,

14 Menhardt, Funde zu Ulrich von Pottenstein, 159-170; see also Baptist-Hlawatsch, Katechetisches Werk, 6; Schmidtke, U. v. Pottenstein; Ernst, Ulrich von Pottenstein, 209; Segl, Waldenser in Österreich, 186-187.

15 Menhardt, Funde zu Ulrich von Pottenstein, 167-168; ÖNB Cod. 3050 is considered to be the most trustworthy exemplar of the Credo-part, and closest to the author's text, see Baptist-Hlawatsch, Katechetisches Werk, 13-20.

16 Menhardt, Funde zu Ulrich von Pottenstein, 167.

17 Ulrich von Pottenstein, Dekalog, 2. Gebot, Cap. L. Transcription of Kalocza Cod. 629 by SFB 226.

18 Segl, Waldenser in Österreich, 186-188.

19 With the permission of the former project leader, Professor Dieter Harmening, I have consulted the transcriptions prepared first in the Sonderforschungsbereich 226 at the beginning of the 1990 s and later around 2000 in an unfinished dissertation project by Christine Wolf, supervised by Harmening.

20 Ulrich von Pottenstein, Dekalog-Auslegung, ed. Baptist-Hlawatsch; Ulrich von Pottenstein, Paternoster-Auslegung, ed. Hayer

21 Välimäki, Awakener of Sleeping Men, 216-230. 
wrote against them around $1260 .{ }^{22}$ In the following century and a half, dissident communities persisted despite occasional persecutions and setbacks, such as the conversion of a group of Waldensian brethren to Catholicism during the 1360 s, possibly due to the inquisitor Henricus of Olomouc's activity. ${ }^{23} \mathrm{~A}$ new series of trials started in the diocese of Passau around 1395 when Petrus Zwicker was nominated as inquisitor of heresy. ${ }^{24}$ Between 1395 and 1398 Zwicker, assisted by Fridericus, a Benedictine monk from Garsten, interrogated probably hundreds if not thousands of Waldensians around Garsten, Steyr and Enns. Only fragments of trial documents survive in formularies compiled from selected sentences, but contemporary and later chronicles recount one thousand convicted and between eighty and one hundred burned heretics. In addition, in the sixteenth century, three large volumes of trial documents - since lost - existed at the library of the Benedictine monastery of Garsten. Even if the numbers recounted in chronicles are probably rounded-up and exaggerated and the information about original depositions at Garsten is vague and unreliable, compared to the over 450 Waldensians Zwicker interrogated in Stettin in 1392-1394 an estimate of several thousand deponents in the more populous Upper Austria region is not an exaggeration. ${ }^{25}$

Petrus Zwicker returned to Austria and its neighbouring areas with another inquisitor, Martinus of Prague, in January 1401, when they sentenced heretics to do public penance by wearing crosses in Ödenburg (now Sopron, Hungary) in the diocese of Györ. In February of the same year, they were at Hartperg in Styria, in the Archdiocese of Salzburg, where three women ended up on the pyre as relapsed heretics and opponents of the inquisitors. ${ }^{26}$ Finally, Zwicker proceeded against a man called Andreas Hesel in Vienna in $1403 \cdot{ }^{27}$ In the diocese of Passau, trials against heretics continued after Petrus Zwicker's death in around 1404. In February 1408, the Landeshauptmann Reinprecht II of Wallsee received oaths of truce and abjuration of all heresy from a widow and her three children who had been imprisoned because of their heresy - her husband and their father had been burned for his heresy. ${ }^{28}$ Reinprecht II of Wallsee was one of the most influential Austrian noblemen in Petrus Zwicker's and Ulrich

22 On the Anonymous's treatise, see Nickson, >Pseudo-Reinerius` Treatise; Patschovsky, Passauer Anonymus; on heretics in Austria in the second half of the thirteenth century, see Segl, Ketzer in Österreich, 165-233.

23 Biller, Aspects, 226; on Henricus of Olomouc, see Haupt, Waldenserthum und Inquisition, 368-369; Gonnet and Molnár, Vaudois au Moyen Âge, 150, 157; Segl, Waldenser in Österreich, 176-177; Modestin, Anti-Waldensian Treatise, 225-226.

24 Since H. Haupt's seminal work on Austrian Waldensians, the beginning of Zwicker's inquisition in the diocese of Passau has been dated to 1391, see Haupt, Waldenserthum und Inquisition, 370, 404; Biller, Anti-Waldensian Treatise, 255; Segl, Waldenser in Österreich, 177; Modestin, Ketzer in der Stadt, 4; Modestin, Peter Zwicker, 28; Modestin, Anti-Waldensian Treatise, 217. The year 1391 is, however, based on a misinterpretation of dates in Zwicker's formulary of sentences. The inquisitions in the diocese of Passau took place in 1395-1398, and the first version of the formulary was compiled soon after that, see Välimäki, Awakener of Sleeping Men, 167-172.

25 Segl, Waldenser in Österreich, 172-184; Välimäki, Awakener of Sleeping Men, 164-174; the chronicle sources are an almost contemporary Austrian chronicle, see Österreichische Chronik von den 95 Herrschaften, ed. Seemüller, 221; and the seventeenth-century Valentin Prevenhuber's Annales, which probably make use of medieval sources, see Preuenhueber, Annales Styrenses, 72.

26 The documents are edited in Haupt, Waldenserthum und Inquisition, 401-403, 408-411.

27 The sentence has been preserved in a single manuscript, Würzburg UB, M. ch. f. 51, fols. 27v-28v. Ed. partially in Döllinger, Beiträge II, 343-344.

28 Vienna, Österreichisches Staatsarchiv, Haus-, Hof- und Staatsarchiv, Allgemeine Urkundenreihe, 1408 II 17; cf. Doblinger, Herren von Walsee, 399; Segl, Die Waldenser in Österreich, 175. For more details, see Välimäki, Awakener of Sleeping Men, 43-44. 
von Pottenstein's lifetime. He was also the lord of the town of Pottenstein, and he donated a plot in Enns so that Ulrich could build a townhouse for a chaplain. In turn, Ulrich established masses for Reinprecht's benefit in his last will in 1416, and one of the manuscripts of his catechetical treatise was dedicated to Reinprecht. ${ }^{29}$

Reinprecht II of Wallsee was not the only mighty and powerful patron Ulrich had. As parson of Pottenstein, Ulrich was a member of the Chapter of St. Stephen in Vienna from the beginning of the 1390s until December 1404, when he was nominated parson of Mödling. Ulrich was closely connected to the ducal court as chaplain of Duchess Beatrix, wife of the deceased Duke Albrecht III, ${ }^{30}$ as well as of Duke Albrecht IV. ${ }^{31}$ As a canon at the cathedral of St. Stephen, Ulrich can hardly have remained ignorant of the trial of Andreas Hesel and his punishment by Petrus Zwicker in the presence of a great multitude of clergy and laity in Vienna in March 1403, although Ulrich is not mentioned among the witnesses. ${ }^{32}$

There has been speculation that Ulrich's anti-Waldensian literary activity might have been motivated by personal gain, namely that Ulrich got hold of some property confiscated from the Waldensians. As parson and dean of Enns-Lorch he did indeed create new benefices and in his testament (1416) he donated significant property to a new chapel in the Church of St. Mary at Enns, property that he had acquired during the preceding years in Upper Austria. Ulrich's patron, the aforementioned Reinprecht of Wallsee, had been Landeshauptmann (governor) at Enns since 1380, and thus responsible for dispensing secular justice in the inquisitions of heresy, including possible confiscations of property. ${ }^{33}$ We cannot, however, be sure if property of the convicted heretics was confiscated at Enns. There were inquisitions in the town, but the only references are brief remarks in Zwicker's later sentences. ${ }^{34}$ In any case, Ulrich would have arrived at Enns too late to gain anything directly from possible confiscations. He received the offices at Enns only in 1411 or 1412, well after he had finished his catechetic summa. ${ }^{35}$ His anti-Waldensian inclinations thus arose from motives other than personal financial gain, but at a general level his writings supported the same goals as the judicial repression of dissidents by secular authorities. The authors and translators of the Wiener Schule wrote practically-oriented theology that was fundamentally in support of the state (a "staatstragende" theology, pace Klaus Wolf). This meant defending the unity of faith

29 Baptist-Hlawatsch, Das Katechetische Werk, 2, 4-5, 53-54, 57.

30 Baptist-Hlawatsch, Einführung, 1*-4*; Baptist-Hlawatsch, Katechetisches Werk, 2-4; Ernst, Ulrich von Pottenstein, 206; Menhardt, Funde zu Ulrich von Pottenstein, 146-147.

31 Lackner, Hof und Herrschaft, 157.

32 Würzburg UB, M. ch. f. 51, fol. 28r: presentibus honorabilibus et discretis viris et dominis petro Schulderwerem plebanus in stewestarff (?), ulrico de gretz et henrico dicto albus predicatoribus apud dictam ecclesiam sancti Stephani et quampluribus fidedignis aliis testibus clericis et laicis ac maxima multitudine hominum plebis dicte parochie ibi ad audiendum verbum dei congregata.

33 Menhardt, Funde zu Ulrich von Pottenstein, 147; Ernst, Ulrich von Pottenstein, 207; Segl, Waldenser in Österreich, 173-175.

34 The only person certainly convicted at Enns was Jans von Pewg, whose sentence for perjury in January 1398 tells that he had first abjured heresy at Enns »one and half years earlier «, see St. Paul, Cod. 77/4, fol. 330va: recognouisti quod ante alterum dimidium annum ex nostro mandato per plebanum tuum vocatus ad nostrum veneris examen ad Anasium et ibi coram nobis de didenda ueritate secundum quod iuris est.

35 On Ulrich's nomination as parson and dean at Enns, see Baptist-Hlawatsch, Einführung, $5^{*}-6^{*}$. 
in the realm and fighting superstition. The anti-Jewish and anti-Hussite endeavours of the university are well known, but Klaus Wolf mentions only briefly the earlier repression of the Waldensians in his extensive study on the Wiener Schule. ${ }^{36}$ Yet precisely this is the broader religious-political context of Ulrich's translations.

Although there is no evidence that Petrus Zwicker and Ulrich von Pottenstein ever met personally, or that Ulrich himself was ever directly involved in prosecuting Waldensians, Ulrich's career contains multiple occasions with the potential for encounters with suspected, convicted or converted Waldensians. Due to the inquisitions that lasted for years, with the accompanying sermons, citations, declarations of sentences and supervision of penances, ${ }^{37}$ the Waldensians inevitably belonged to the contemporary clergy's experience in Austria. This explains the popularity of Zwicker's texts in Austria and Southern Germany, as well as Ulrich's decision to translate the Cum dormirent homines and incorporate it into his catechetical treatise. The treatise was available to him relatively easily: the earliest copies of the Cum dormirent homines date to the time when Ulrich composed his treatise. A few come from Austria, although none of them is the exemplar Ulrich used. ${ }^{38}$

\section{Translating heresy}

How does one fit a polemical treatise into a catechetical compendium? The first remarkable thing is that Ulrich did not simply quote short passages from the Cum dormirent homines but translated practically the whole treatise. Secondly, it is equally remarkable that he did not translate it as a unit. There is no one single book or chapter on Waldensians, but chapters of Zwicker's treatise are divided and assimilated under various different topics. Neither did Ulrich follow the order of the Cum dormirent homines. Several chapters precede the translation of the beginning of Zwicker's treatise, and thus his prologue and introduction to the history of Waldensian movement.

The beginning of the Cum dormirent homines, along with several other chapters, was translated in the Credo part in chapter $35 .{ }^{39}$ However, long passages from the treatise precede this in Ulrich's work. For example, the Cum dormirent homines' chapter about burial in consecrated ground is inserted into the Credo chapter 27, treating different aspects of Christian burial according to the example set by Christ's tomb after his crucifixion. Waldensians are simply inserted into the text without any previous warning or explanation to the reader. Chapters immediately preceding the translation from Zwicker's treatise deal with whether or not executed criminals can be given Christian burial, and if women who died while pregnant could be buried with their foetus. Only a short introduction leads the reader to anti-heretical sections, from pastoral and canon legal reflections into theological refutation of Waldensian doctrine:

36 Wolf, Hof - Universität - Laien, 118-130 (in general), 193-194 (on Waldensians); on Ulrich von Pottenstein against superstition, see Lasson, Superstitions Médiévales, 205-416.

37 On the various fora of an inquisitor's communication, see Välimäki, Awakener of Sleeping Men, 184-213.

38 Seitenstetten, Cod. 213, fols. 108va-133ra; St. Florian, XI 234, fols. 93ra-112rb; Vienna ÖNB, Cod. 5393, fols. 287va-305vb; Zwettl, Cod. 185, fols. 121rb-141rb.

39 Including Chapters 1-18, 25-29, and 31-35, according to the division in Petrus Zwicker, Cum dormirent homines, ed. Gretser. 
However much burial has a deep and solid foundation in the Old and New Testaments and in holy laws, nevertheless the impious Waldensian heretics speak against it and suppose in their error that a corpse of a dead person is not better buried in a church or in a graveyard than in a field or some other place. ${ }^{40}$

This reveals the tension between Ulrich's goal of bringing Latin learning to the laity and the practical solutions he employs. His translation from Zwicker made available to the reader what was in fact one of the best medieval introductions to what Waldensians were, but in Ulrich's schema it is situated over 150 folios apart from the sudden appearance of the heretics in the discussion of burial. Other topics from Zwicker's treatise were also scattered: the chapters on the consecration of churches (Cum dormirent homines: 23), altars (24) and on the veneration of Mary and the saints (19) and of God (20) are all dispersed within Ulrich's chapter 33 on the verse Ich gelaub in die heyligen gemainen kyrchen, gemainschafft der heyligen (I believe in the holy Catholic Church, and the communion of saints) ${ }^{41}$ When encountering one of these topics, the reader is simply assumed to know what the simpious Waldensian heretics « were. The Vienna manuscript anticipates some confusion. Marginalia are rare in this manuscript, but here the scribe has given a Latin rubric when the discussion on Waldensians begins in the chapter on burial: Contra waldenses de sepultura..$^{42}$

Yet here one has to remember that to the immediate contemporaries of Ulrich the reference to Waldensians might have been as clear as day. As stated above, Waldensians were a public concern, and in Austria at the turn of the fifteenth century the whole apparatus of citations, inquisitor's preaching and public penance made it hard to be ignorant of heretics. A Western audience of the twenty-first century has a preconception of what an Islamist terrorist is - similarly the Austrian audience at the turn of the fifteenth century must have had some impression about the Waldensians. It was most likely a one-sided and distorted conception, but nevertheless something that helped to situate an abrupt mention of Waldensians into a larger scheme of things.

When an anti-heretical treatise was translated and incorporated into a catechetic summa, one would anticipate some compromises with regards to the polemical language. Moreover, Zwicker's trademark is a personal, dialogical and disputing style, where he addresses his heretical opponents in the second person - Zwicker adopted this style from one of his sources, the Adversus Catharos et Valdenses by Moneta of Cremona, while the more common solution in contemporary anti-heretical treatises was to speak about heretics in the third person. ${ }^{43}$ However, against this expectation, Ulrich preserved both these stylistic features in his German version. Let us look at one passage where Waldensian counter-argument on secret preaching is answered, followed by a comparison of heretics to nocturnal animals.

\footnotetext{
40 Ulrich von Pottenstein, Credo, Cap. 27M, ÖNB Cod. 3050 fols. 103va-vb: Wie wol die begrebnuss aus der alten ee vnd aus der newen ee vnd aus den heyligen rechten ainen tewffen vnd vesten grunt haben, dannoch widersprechen ir die vnseligen keczer Waldenses vnd halden daz in irem irrsal, daz aines toten menschen leichnam nicht paz begraben werd in ainer kirchen oder in ainem freythof denn in ainem akcher oder an ainer andern stat.

41 Ulrich von Pottenstein, Credo, Cap. 33, ÖNB Cod. 3050 fol. 244ra-259ra.

42 ÖNB Cod. 3050, fol. 103vb.

43 Biller, Anti-Waldensian Treatise, 258-261; Välimäki, Awakener of Sleeping Men, 81-82.
} 
Petrus Zwicker, Cum dormirent homines, ed. Gretser, 279G

Sed dicis Waldensis haeretice: Tamen Christus docuit Nicodemum in nocte de Sacramentorum exordio, scilicet de Baptismate, Ioann.3.

Respondeo, Christus non venit ad Nicodemum sed Nicodemus ad Christum. Tu vero fur et latro, lupe, glis et vespertilio, noctua caeca nocte ad simplices volias, cursitans circuis quaerens quem deuores.

Ulrich von Pottenstein, Credo, Cap. 35C, ÖNB, Cod. 3050, fol. 278vb:

Da wider sprichst du keczer Waldensis: Nu leret doch Christus Nychodemum bey der nacht von dem aneuang der sacrament, von der tawffe, Iohannis iijo.

Die antwurt: Christus cham nicht zu Nychodemo, aber Nychodemus cham zu im. Aber du dewb vnd schacher, fuchs, fledermaws vnd nachtrab, du flewgest plint des gelauben des nachtes czu den ainueltigen. Du lawffest vmb vnd vmb vnd suchest, wen du czu reissest.

[English translation of Ulrich's text:] Against that speak you, Waldensian heretic: [saying] after all, Christ taught Nicodemus at night about the origin of the sacrament, baptism, John 3.

The answer: Christ did not come to Nicodemus, but Nicodemus came to him. But you, thief and robber, fox, bat and owl, you fly blinded by the faith of night to the simple people. You go around and around and seek out, whom to snatch away.

The second person and denigrating language are preserved: both in Latin and in German, the heretic is compared to criminals and nocturnal animals, moving around and seeking victims to devour. But while thief and robber (fur et latro) are translated with corresponding German words (dewb vnd schacher ${ }^{44}$ ), some creativity is used in translating the night animals. The wolf becomes a fox, the glis (a dormouse) is dismissed, but the bat and the owl (vespertilio, noctua) are both translated (fledermaws vnd nachtrab). The dismissal of the glis may be a simple accident, but it may also be that the Latin word carried a connotation of a secretive night animal while the contemporary German did not. After all, the small, big-eyed rodent is not very intimidating.

Also the blindness is explained a bit more than in Zwicker's Latin. Here, the heretic/ night animal is simply sblinded by night ( caeca nocte), while in Ulrich's German ‘blinded by the faith of night ( plint des gelauben des nachtes). This is obviously also the connotation in Zwicker's polemical language. But the Latin, written for a clerical audience, allowed metaphors that remained implicit, whereas the German prose of the Wiener Schule aimed for unambiguous, uncontroversial devotional literature that a lay audience could read without fear of error and misinterpretation. ${ }^{45}$ Ulrich was loyal to this ideal. The need to expand the original text in order to be intelligible is even more visible in the translation of a metaphor where Zwicker blames Waldensians for claiming that in heavenly joys, saints forget those living on earth, ras if they, when things prospered with them, would have forgotten us, as Pharaoh's chief cupbearers forgot Joseph, his imprisoned interpreter, Gen. 40. ${ }^{46}$ The story

44 More likely to be read as Schächer (robber, thief) than Schacher (usurer). The latter reading would add another polemical layer to the text with an allusion to Jews.

45 Wolf, Hof - Universität - Laien, 188-189.

46 Petrus Zwicker, Cum dormirent homines, ed. Gretser, 286B-C. 
behind the metaphor is of Joseph interpreting correctly that the dream of Pharaoh's imprisoned cupbearer foretold his release, and that the cupbearer in his freedom forgot Joseph against the latter's wish. Ulrich translates the passage: "as if they would forget us in their fortune, as Pharaoh's chief cupbearer did pious Joseph, who forgot him in the prison, although he had explained his [cupbearer's] dream and prayed for him, that he would remember him. ${ }^{47}$ Although Ulrich's translation with its several male pronouns referring to different persons is more confusing than Zwicker's original, it seems that the good intention was to explain the story in greater detail than Zwicker. Obviously the challenge with Zwicker's biblicist polemical language was the preliminary knowledge of exegetical and glossing tradition it required from its reader. ${ }^{48}$ This knowledge could not be expected of a layperson. Ulrich attempted to solve this problem, but the result was not very accessible literature, despite his own wish to write den gemainen lauf dewtscher sprach nach des lanndes gewonhait and in the way one should preach to the people, and avoid a too-learned vernacular. ${ }^{49}$

That Ulrich translated not only the content of his source but also the style is in accordance with the previous conclusions drawn from his use of sources: Gabriele Baptist-Hlawatsch has pointed out how loyally Ulrich copied the style of William Peraldus's Summa de vitiis et virtutibus..$^{50}$ In other words, there are changing registers of speech and style in Ulrich's compendium. However, the polemical style and colourful rhetoric in general do not seem to have been foreign to Ulrich. Also, in parts that he possibly wrote himself, such as a lamentation about the bad prelates of his own day in the Pater noster part, Ulrich uses language that is not catechetic, guiding or normative, but outright polemical. Prelates, who oppress the poor people more than godless pagans, are like vultures devouring their children. Some are compared to bats that live in the dark places of the churches, enjoying prebends and loving darkness because of the dirty carnal deeds they commit there. Like bats, they are blind, not knowing the scriptures..$^{51}$ Notably, the same German word fledermaws is used both for bad prelates and for the heretics. The comparison of darkness, nocturnal gatherings, animals, and sexual sins is a lasting element of anti-heretical literature from late Antiquity onwards..$^{52}$ At times, Ulrich is more polemical than his source, the inquisitor Zwicker, who was careful to limit his attack to the Waldensians and avoid mentioning the shortcomings of the contemporary Church, of which he was more than aware. The opening clause of Cum dormirent homines, 'when men were asleep<, alluded in medieval exegesis to the negligence of the clergy as the cause of heresy, but in the Latin treatise the reference remains implicit. ${ }^{53}$

47 Ulrich von Pottenstein, Credo, ÖNB Cod. 3050, fols. 258va-vb: Recht als ob si vnser vergéssen in irem gelücke, als der obrist schenke Pharaonis tet dem frumen Ioseph, der sein vergaz in dem karcher, wie wol er im seinen trawm hette warhafftleichen erleget vnd pat in, daz er sein gedęchte.

48 On Zwicker's biblicism, see Välimäki, Awakener of Sleeping Men, 98-109.

49 Ulrich von Pottenstein, Dekalog-Auslegung, ,Vorrede،, ed. Baptist-Hlawatsch, 2-3; see also Baptist-Hlawatsch, Einführung, 36*-39*; Wolf, Hof - Universität - Laien, 194; cf. Lasson, Superstitions Médiévales, 72-73, who accepts Ulrich's own statement of his style.

50 Baptist-Hlawatsch, Einführung, 30*-36*, 425; see also Wolf, Hof - Universität - Laien, 345-355.

51 Ulrich von Pottenstein, Paternoster-Auslegung, Cap. 7D, ed. Hayer, 154-157.

52 See e.g. Kahlos, Nocturnal Rituals; Grundmann, Typus des Ketzers, 322-325; Utz Tremp, Von der Häresie zur Hexerei, 31-32.

53 Välimäki, Awakener of Sleeping Men, 226, 269-270. 
In his translation, however, Ulrich von Pottenstein significantly expands the exposition of the parable and makes it clear that heresy and error spread when the prelates are negligent, obscene or weighed down by sins. ${ }^{54}$ Not only heretics, but also sinful clerics received the polemical edge of Ulrich's catechesis, and his attack on bad clerics seems deliberate. When translating Peraldus's Summa, Ulrich did not leave out sections that describe the vices of priests and religious orders - unlike some other vernacular versions of Peraldus's Latin treatise. ${ }^{55} \mathrm{An}$ open criticism of the clergy in vernacular by a clergyman himself holding relatively high offices is indeed intriguing, but perhaps not as radical as one might think. Ulrich's lay audience, at least those who could afford to buy his treatise, was not common craftsmen but well-off burghers and nobility who had interests in the affairs of the Church.$^{56}$ Nevertheless, refuting Waldensians served a purpose. Ulrich could condemn the dangerous, heretical anticlericalism while at the same time launching an attack on corrupt members of the Church.

Ulrich thus resorted to literary devices of a polemical style, also in some of his original passages. This leads us to reflect on why Ulrich chose to incorporate an anti-heretical polemic into a catechetical treatise, and how Ulrich's work can be placed within the discourses that modern scholars define as polemics.

\section{Pastoral polemics}

The goal that Ulrich sets for his work in his Preface is to compile a book that would serve only its reader's soul and its eternal salvation - as opposed to the immoral tales of war (streytbüchern) Ulrich saw his contemporaries reading. ${ }^{57}$ The incorporation of Zwicker's treatise must be thought about in the light of this goal. Ulrich in fact gives a short explanation for why he has written so much about heresy. At the end of the long Chapter 35, where the bulk of the Cum dormirent homines is translated, Ulrich tells his reader:

But that I have written so long and so much about heretics in this chapter: I am driven to this, because they are those who in so many ways, so deceitfully and mischievously oppose the universal holy Christian Church, which is the only dove which alone is beautiful, which alone is transcendent (auszerwelt), which alone is without wrinkle and without blemish, and they defile her (the Church) in all her parts, her glory and order, wherever and how often they are capable. ${ }^{8}$

54 Ulrich von Pottenstein, Credo, Cap. 35A, ÖNB Cod. 3050, fols. 276rb-va: „Do aber die lewte slieffen «, daz ist die hüter, die czu der hüt geordent sein vnd den die huet empholhen ist, daz sein die prelaten, der slaf vnd vmbesichtichait machet, daz der veintleich mensch, der tewfel, raten saet, wenn die prelaten slaffen, wenn sy tregge sind. Wider die spricht Salomon Prouerbiorum vj': "Lawf, eyl, wekche deinen frewnt. Gib deinen awgen chainen slaff." Oder wenn sy der vnkewsch phlegen. Da wider ist Amos capitulo vj': "Ir seyt die, dy da slaffen in helfenpaynein petten vnd seyt gail darinnen. "Oder wenn si mit sünden besweret werden. Da wider ist is Paulus $2^{\circ}$ Thessalonicenses iij: "Wir sullen nicht slaffen als dy andern, aber wir sullen wachen vnd mässig sein."

55 Baptist-Hlawatsch, Einführung, $35^{*}$.

56 In addition to the lay elite, many sections of the treatise were clearly primarily intended for the clergy, see BaptistHlawatsch, Einführung, $36^{*}-37^{*}$.

57 Ulrich von Pottenstein, Dekalog-Auslegung, ,Vorredes, ed. Baptist-Hlawatsch, 2.

58 Ulrich von Pottenstein, Credo, 35, ÖNB Cod. 3050, fol. 289va: Daz aber ich so lang vnd so uil in dem capitel von den keczern geschriben han, darczu hat mich geübt, wann si sind dü, die der gemainen heyligen christenleichen kirchen, die ain ainige tawbe ist, die allain die schön ist, die allain die auszerwelt ist, die allain an alle runczen ist vnd an mail, so gar manigueltichleich, listichleich vnd schalkchleich widersprechen vnd si lestern in iren glidern vnd in irer czir vnd ordnung, wa vnd wie offte si daz volbringen mügen. 
The goal motivating Ulrich was thus the usual reason for writing Christian apologetics: to defend the Church against its enemies. But because of the decision to divide the Cum dormirent homines' structure, the end result was a very different reading experience from a more usual anti-heretical text. For example, Zwicker's treatise proceeds from the history of the Waldensians and their claims of being legitimate followers of the apostles to individual heretical opinions and Catholic counter-arguments. A full polemical treatise such as the Cum dormirent homines usually aimed to provide a complete representation of heretics and especially their doctrine, which was then systematically refuted..$^{59} \mathrm{~A}$ reader who encountered Ulrich's translation may only have read, for example, the chapter on Christian burial. Ulrich never intended his work to be read as a whole, but thematically. He prepared an index for the whole work, using alphabetically organised Latin-German keywords (for example: aqua) Wasser) and references to chapter number and letter. The index for the whole work has not been preserved, only indices for individual parts, but Baptist-Hlawatsch has reconstructed the register. ${ }^{60}$

However, if the goal of polemical engagement is understood as establishing "an identity, defined against the wrong or wicked «, ${ }^{61}$ Ulrich's sturcture has even greater polemical potential than many texts usually defined as anti-heretical polemics. By dispersing the chapters of the Cum dormirent homines, by integrating the negative image of heretics within chapters giving positive, normative guidelines for a good Christian life, Ulrich juxtaposes the heretical and the orthodox in a way that does not manifest itself in conventional anti-heretical polemic. Waldensianism as a negative image of the Church, created by a sort of snormative inversion<, to employ a term used by Jan Assmann, ${ }^{62}$ is implicit in the Cum dormirent homines, as well as in the shorter descriptions of Waldensians circulating at the time. All of them accuse the Waldensians of denying practically every important aspect of late medieval religious life. Although not creating a complete counter-society like the authors discussed by Assmann there was after all no denying that the Waldensians upheld baptism and the Eucharist - these descriptions employ the logic that things venerated by Catholics such as church buildings or sacerdotal vestments must be despised and condemned by the heretics. Yet, it is only in Ulrich's catechism that this message becomes explicit.

A combination of pastoral, didactic and polemical voices is not unique. Recently, Almut Suerbaum has found such a combination in the sermons of one of the most successful mendicant preachers of the thirteenth century, the Franciscan Berthold of Regensburg. His vernacular sermons were pastoral care for urban communities where he preached, but his language has two different tones: one castigating the shortcomings of the attending laity, and another attacking the heretics and their false beliefs. The latter message was, of course, also aimed at the Christian listeners. Berthold's sermons do not attempt to persuade heretics to convert, but focus on warning the Catholic audience to avoid heretics' mistakes for the good of their own souls. ${ }^{63}$ There is a comparable shift of emphasis and audience from Zwicker's

59 Sackville, Heresy and Heretics, 13-40.

60 Baptist-Hlawatsch, Katechetisches Werk, 209-322; see also Wolf, Hof - Universität - Laien, 193.

61 Southcombe et al., Introduction, 6; Steckel, Concept of »Polemic«.

62 Assmann, Moses der Ägypter, 57-58, 90.

63 Suerbaum, Language of Violence, 128, 130. 
Cum dormirent homines to Ulrich's translation. Even though the readership of Zwicker's treatise must have consisted of Catholic clergy, the text addresses Waldensians. Stylistically it is a debate, and at least in theory, an attempt at persuasion to convert. Although Ulrich preserved the second person ( $d u$ keczer) the division of anti-Waldensian sections under different topics means that the primary function of the polemic was to warn a Christian reader. If a heretic was the imagined audience of Zwicker's refutation, Ulrich hardly had such a reader in his mind.

Incorporation of polemical passages into a text that has also - and perhaps primarily other functions than polemical confrontation is not rare. In addition to Suerbaum's analysis of Berthold of Regensburg, Southcombe, Suerbaum and Thompson provide an example of John Milton's Lycidas (1638) where lyrical pastoralism bursts into violent exhortation against the corrupt clerics of his own days. According to them, the containment of polemics within particular social, discursive or generic conventions is one of the features that cut across pre-modern polemics. ${ }^{64}$ My case-study of Ulrich von Pottenstein supports this conclusion.

Potentially, Ulrich's translation expanded Zwicker's audience. In practice, however, that was hardly the case. Ulrich's huge treatise never became popular, and with its eleven preserved manuscripts it stayed far behind the readership of the Wiener Schule's more successful works. In addition, some of the manuscripts refer to a monastic audience, ${ }^{65}$ and religious houses also furnished the main readership of Zwicker's original work. With circa 50 extant manuscripts, the latter was far more popular than Ulrich's translation, which in theory could have reached more readers.

There is, however, a certain emphasis on the anti-Waldensian sections among the preserved copies of Ulrich's catechetical encyclopedia. Seven out of eleven manuscripts include at least one whole translated chapter from Cum dormirent homines. Considering that the translation covers fewer than 30 folios within a work of 1200 folios, most of them in the Credo part, the number is not insignificant. In addition, a scribe and a later commentator of the Austrian National Library Cod. 3050 showed particular interest in Waldensians, adding Latin rubrics and marginalia to the index and some anti-Waldensian chapters. ${ }^{66}$ Such metatextual elements are otherwise rare in this manuscript. The evidence is indecisive, but implies that if any part of the encyclopedia attracted attention, it was the translation of the Cum dormirent homines. Had Ulrich von Pottenstein not buried the translation in his gargantuan work, it could have been much more popular and influential.

\section{Conclusions}

Genre borders are always arbitrary, and especially so in compilatory works such as Ulrich von Pottenstein's catechetic treatise. A combination of different sources, which Ulrich translated very loyally, created variation in style and tone in his work. Polemical refutation of heresy found its place among didactic, pastoral and legal passages, and in a thematically structured reference book one register changes into another, sometimes abruptly. Polemical style is not exclusive to the translations of Petrus Zwicker's anti-Waldensian Cum dormirent

64 Southcombe et al., Introduction, 10-11.

65 Wolf, Hof - Universität - Laien, 190-194. On the manuscript tradition, see n. 4 above.

66 ÖNB Cod. 3050, fols. 8v, 9r, 103v, 276v, 277r, 277v, 346vb; see also Välimäki, Awakener of Sleeping Men, 221-222. 
homines: passages that Ulrich most likely wrote himself also contain denigrating language. When describing sthe sleeping men<, Ulrich's translation is, in fact, more accusatory towards the negligent clergymen than Zwicker's original.

Detecting polemics in pastoral and didactic texts is tedious, especially so because much of the late medieval devotional literature is edited only partially, if at all. Changes in style can be unexpected, and polemical sections do not necessarily manifest themselves in indices and rubrics. In this aspect Ulrich's catechetic encyclopedia is actually quite accessible: without Ulrich's own register with its keyword keczer guiding to the anti-heretical sections, his translation of Zwicker's polemic might well have gone unnoticed. Nevertheless, wading through the manuscript leaves is worth the trouble: there seems to be a polemical element or current in late medieval pastoral literature, which has so far not been fully recognised. This dark side of pastoral care is a promising area of research, as we proceed to write a revised history of polemical literature, style and genre.

\section{Acknowledgements}

The research for this article has been funded by the Academy of Finland. Project Profiling Premodern Authors, project number 293024. 


\section{References}

Manuscripts and archival sources

Seitenstetten, Stift Seitenstetten, Cod. 213

SFB 226 Würzburg/Eichstätt. Teilprojekt 5: Ulrich von Pottenstein, Ketzerstellen: Dekalog.

Unpublished transcription from Kalocsa Föszékesegyházi Könyvtár, Ms. 629.

St. Florian, Stift St. Florian, XI 234

St. Paul im Lavanttal, Stift St. Paul, Cod. 77/4

Vienna, Österreichische Nationalbibliothek (ÖNB)

Cod. 3050

Cod. 5393

Vienna, Österreichische Staatsarchiv (ÖStA), Haus-, Hof- und Staatsarchiv (HHStA)

Allgemeine Urkundenreihe 1408 II 17

Würzburg Universitätsbibliothek (UB)

M. ch. f. 51

Zwettl, Stiftsbibliothek,

Cod. 185

Published sources and literature

Assmann, Jan, Moses der Ägypter. Entzifferung einer Gedächtnisspur (seventh edition), (Frankfurt am Main, 2011).

Baptist-Hlawatsch, Gabriele, Das Katechetische Werk Ulrichs von Pottenstein. Sprachliche und rezeptionsgeschichtliche Untersuchungen (Tübingen, 1980).

Baptist-Hlawatsch, Gabriele, Einführung, in: Gabriele Baptist-Hlawatsch (ed.), Ulrich von Pottenstein, Dekalog-Auslegung: Das erste Gebot. Text und Quellen (Tübingen, 1995) 1*-64*.

Biller, Peter, Aspects of the Waldenses in the Fourteenth Century, Including an Edition of their Correspondence. Unpublished PhD Thesis (University of Oxford, 1974).

Biller, Peter, The Anti-Waldensian Treatise Cum Dormirent Homines of 1395 and its Author, in: The Waldenses, 1170-1530: Between a Religious Order and a Church (Aldershot, 2001) 237-269.

Bodemann-Kornhaas, Ulrike, Die Cyrillusfabeln und ihre deutsche Übersetzung durch Ulrich von Pottenstein. Untersuchungen und Editionsprobe (München, 1988).

Doblinger, Max, Die Herren von Walsee. Ein Beitrag zur österreichischen Adelsgeschichte, Archiv für österreichische Geschichte 95 (1906) 335-578.

Döllinger, Johann Joseph Ignaz von, Beiträge zur Sektengeschichte des Mittelalters. Zweiter Theil. Dokumente vornehmlich zur Geschichte der Valdesier und Katharer (München, 1890).

Ernst, Peter, Ulrich von Pottenstein. Leben und Werk nach dem Stand der neueren Forschung, Unsere Heimat 58 (1987) 203-213.

Gonnet, Jean and Molnár, Amedeo, Les Vaudois au Moyen Âge (Torino, 1974).

Grundmann, Herbert, Der Typus des Ketzers in mittelalterlicher Anschauung, in: Ausgewählte Aufsätze, Schriften der Monumenta Germaniae Historica 1 (Stuttgart, 1976) 313-327.

Haupt, Herman, Waldenserthum und Inquisition im südöstlichen Deutschland seit der Mitte des 14. Jahrhunderts, Deutsche Zeitschrift für Geschichtswissenschaft 3 (1890) 337-411.

Hayer, Gerold, Paternoster-Auslegung. Nach der Handschrift a X 13 des Erzstiftes St. Peter zu Salzburg kritisch herausgegeben und eingeleitet. I. und III. Teil. Unpublished PhD Thesis (University of Salzburg, 1972). 
Hohmann, Thomas, ১Die recht gelerten maister«. Bemerkungen zur Übersetzungsliteratur der Wiener Schule des Spätmittelalters, in: Fritz Peter Knapp and Herbert Zeman (eds.), Die Österreichische Literatur. Ihr Profil von den Anfängen im Mittelalter bis ins 18. Jahrhundert (1050-1750), (Graz, 1986) 349-365.

Kahlos, Maijastina, Nocturnal Rituals as an Othering Device: The Long Life of Fears and Labels in Ancient Polemic and Legislation, in: Raimo Hakola, Nina Nikki and Ulla Tervahauta (eds), Others and the Construction of Early Christian Identities (Helsinki, 2013) 313344 .

Lackner, Christian, Hof und Herrschaft. Rat, Kanzlei und Regierung der österreichischen Herzoge (1365-1406), (Wien, 2002).

Lasson, Emilie, Superstitions médiévales. Une analyse d'après l'exégèse du premier commandement d'Ulrich de Pottenstein (Paris, 2010).

Menhardt, Hermann, Funde zu Ulrich von Pottenstein (etwa 1360-1420), in: Festschrift für Wolfgang Stammler zu seinem 65. Geburtstag dargebracht von Freunden und Schülern (Berlin, 1953) 146-171.

Modestin, Georg, Ketzer in der Stadt. Der Prozess gegen die Strassburger Waldenser von 1400, Monumenta Germaniae Historica, Studien und Texte 41 (Hannover, 2007).

Modestin, Georg, Peter Zwicker (gest. nach dem 7. Juni 1404), in: Friedrich Andreae (ed.), Schlesische Lebensbilder 10 (Breslau, 2010) 25-34.

Modestin, Georg, The Anti-Waldensian Treatise Cum Dormirent Homines: Historical Context, Polemical Strategy, and Manuscript Tradition, in: Michael Van Dussen and Pavel Soukup (eds), Religious Controversy in Europe, 1378-1536 (Turnhout, 2013) 211-229.

Nickson, M., The >Pseudo-Reinerius« Treatise, the Final Stage of a Thirteenth Century Work on Heresy from the Diocese of Passau, Archives d'histoire doctrinale et littéraire du moyen âge 42 (1967) 255-314.

Österreichische Chronik von den 95 Herrschaften, ed. Joseph Seemüller, MGH Deutsche Chroniken 6 (Hannover, 1909).

Patschovsky, Alexander, Der Passauer Anonymus: Ein Sammelwerk über Ketzer, Juden, Antichrist aus der Mitte des 13. Jahrhunderts, MGH, Schriften 22 (Stuttgart, 1968).

Sackville, Lucy J., Heresy and Heretics in the Thirteenth Century: The Textual Representations (York, 2011).

Schmidtke, Dietrich, Ulrich von Pottenstein, in: Lexikon des Mittelalters VIII (München, 1997) 1200-1201.

Segl, Peter, Die Waldenser in Österreich um 1400. Lehren, Organisationsform, Verbreitung und Bekämpfung, in: Albert de Lange and Kathrin Utz Tremp (eds.), Friedrich Reiser und die "waldensisch-hussitische Internationale" im 15. Jahrhundert. Akten der Tagung ÖtisheimSchönenberg, 2. bis 4. Oktober 2003 (Heidelberg, 2006) 161-188.

Segl, Peter, Ketzer in Österreich (Paderborn, 1984).

Southcombe, George, Suerbaum, Almut and Thompson, Benjamin, Introduction, in: Almut Suerbaum, George Southcombe and Benjamin Thompson (eds.), Polemic: Language as Violence in Medieval and Early Modern Discourse (Farnham, 2015) 1-14.

Steckel, Sita, Une querelle des théologiens? The Concept of « Polemic » in the Historiography of the Secular-Mendicant Controversy, in: Bénédicte Sère (ed.), Polémologies Médiévales, forthcoming.

Suerbaum, Almut, Language of Violence: Language as Violence in Vernacular Sermons, in: Almut Suerbaum, George Southcombe and Benjamin Thompson (eds.), Polemic: Language as Violence in Medieval and Early Modern Discourse (Farnham, 2015) 125-148. 
Ulrich von Pottenstein, Dekalog-Auslegung: Das erste Gebot. Text und Quellen, ed. Gabriele Baptist-Hlawatsch, Texte und Textgeschichte 43 (Tübingen, 1995).

Ulrich von Pottenstein, Paternoster-Auslegung. Nach der Handschrift a X 13 des Erzstiftes St. Peter zu Salzburg kritisch herausgegeben und eingeleitet. II. Teil, ed. Gerold Hayer. Unpublished PhD Thesis (University of Salzburg, 1972).

Utz Tremp, Kathrin, Von der Häresie zur Hexerei. »Wirkliche« und imaginäre Sekten im Spätmittelalter (Hannover, 2008).

Valentin Preuenhueber, Annales Styrenses: Sammt dessen übrigen historisch- und genealogischen Schrifften, zur Erläuterung der österreich. steyermärckischen und steyerischen Geschichten, (Nürnberg, 1740).

Välimäki, Reima, The Awakener of Sleeping Men. Inquisitor Petrus Zwicker, the Waldenses, and the Retheologisation of Heresy in Late Medieval Germany. Unpublished PhD Thesis (University of Turku, 2016).

Williams-Krapp, Werner. Konturen einer religiösen Bildungsoffensive. Zur literarischen Laienpastoration im 15. und frühen 16. Jahrhundert, in: Andreas Meyer (ed.), Kirchlicher und religiöser Alltag im Spätmittelalter. Akten der internationalen Tagung in Weingarten, 4.-7. Oktober 2007 (Ostfildern, 2010) 77-88.

Williams-Krapp, Werner, Observanzbewegungen, monastische Spiritualität und geistliche Literatur im 15. Jahrhundert, Internationales Archiv für Sozialgeschichte der Literatur 20 (1995) 1-15.

Wolf, Klaus, Hof - Universität - Laien. Literatur- und sprachgeschichtliche Untersuchungen zum deutschen Schrifttum der Wiener Schule des Spätmittelalters, (Wiesbaden 2006).

Wolf, Klaus, Propter utilitatem populi: Durch des nucz willen seines volkes. Die sstaatstragender Rezeption der 'Summa de vitiis` des Guilelmus Peraldus in der spätmittelalterlichen Wiener Schule, in: Christoph Flüeler and Martin Rohde (eds), Laster im Mittelalter (Berlin, 2009) 187-199.

Zwicker, Petrus, [Cum dormirent homines.] [Pseudo]-Petri de Pilichdorf contra Haeresin Waldensium Tractatus, in: Lucae tvdensis episcopi, Scriptores aliqvot svccedanei contra sectam waldensivm, ed. Jakob Gretser, in: Maxima bibliotheca veterum patrum et antiquorum scriptorum ecclesiasticorum, vol XXV, ed. Marguerin de la Bigne (Lvgdvni, 1677) 277F-299G. 